\title{
FACTORS THAT AFFECT THE THERMAL STABILITY OF BOVINE MILK AND THE USE OF ALCOHOL TEST IN THE MILK INDUSTRY - A REVIEW
}

\author{
ROSA, Patricia Pinto da ${ }^{1}$ \\ ÁVILA, Bianca Pio ${ }^{2}$ \\ ANGELO, Isabelle Damé Veber ${ }^{3}$ \\ SILVA, Paula Moreira da ${ }^{4}$ \\ CHESINI, Rodrigo Garavaglia ${ }^{5}$ \\ MOTA, Gilliany Nessy ${ }^{6}$ \\ SEDREZ, Pamela Aristimunho ${ }^{7}$ \\ FERNANDES, Tiago Albandes ${ }^{8}$ \\ BUGONI, Milena ${ }^{9}$ \\ ROLL, Victor Fernando Buttow ${ }^{10}$
}

Recebido em: 2020.01.09 Aprovado em: 2020.08.21 ISSUE DOI: $10.3738 / 21751463.3734$

SUMMARY: The dairy industry requires good quality milk with an adequate yield that does not affect the industrial process. Therefore, to produce safe food for consumers aiming to increase the shelf life of the product, the before mentioned industry makes use of heat treatment (pasteurization or UHT - Ultra-high Temperature processing). Milk must have adequate quality and high-temperature resistance; otherwise, thermal stability problems may occur. The alcohol or alizarin test is used in dairy farms to identify milk samples that present over the normal acidity and to measure their stability before being transported to the consumer market. Thus, the objective of this review was to search, in the literature, for evidence regarding the factors that interfere in the heat stability of milk and the use of the alcohol test. False-positive results are usual in samples that make use of that test, showing cases of unstable non-acid milk and putting in jeopardy the reliability of the results.

Keywords: Casein; Chemical composition; Stability; Milk quality.

\section{FATORES QUE AFETAM A ESTABILIDADE TÉRMICA DO LEITE BOVINO E A UTILIZAÇÃO DO TESTE DO ÁLCOOL NA INDÚSTRIA DE LÁCTEOS - UMA REVISÃO}

Resumo: A indústria de lácteos requer leite de boa qualidade, com rendimento adequado e que não afete o processo industrial. Portanto, para a produção de alimentos seguros ao consumidor, visando aumentar o prazo de validade do produto, a indústria faz utilização de tratamento térmico (pasteurização ou UHT- ultra-high temperature). O leite precisa apresentar adequada qualidade e resistência a altas temperaturas, caso contrário problemas de estabilidade térmica podem ocorrer. O teste do álcool ou alizarol é utilizado na propriedade leiteira para identificar amostras de leite com a acidez acima do normal e mensurar a estabilidade do produto antes do transporte para a indústria. Desta maneira, objetivou-se com esta revisão buscar na literatura evidências sobre os fatores que interferem na estabilidade térmica do leite e na utilização do teste do álcool. Resultados falso-positivos são comuns em amostras que utilizam este teste, evidenciando casos de leite instável não ácido e colocando em dúvida a confiabilidade dos resultados.

Palavras-Chave: caseína, composição química, estabilidade, qualidade do leite

\footnotetext{
${ }^{1}$ Federal University of Pelotas, Post Graduate Program in Animal Science (PPGZ)

${ }^{2}$ Federal University of Pelotas, Post Graduate Program in Food Science and Technology (PPGCTA)

${ }^{3}$ Federal University of Rio Grande do Sul, Animal Science Graduate Program (PPGZ)

${ }^{4}$ Federal University of Pelotas, Post Graduate Program in Animal Science (PPGZ)

${ }^{5}$ University of São Paulo, Graduate Program in Animal Nutrition and Production (PPGNPA)

${ }^{6}$ Federal University of Pelotas, Animal Science Graduate Program (PPGZ)

${ }^{7}$ Federal University of Pelotas, Graduate Program in Parasitology (PPGP)

${ }^{8}$ Federal University of Pelotas, Animal Science Graduate Program (PPGZ)

${ }^{9}$ University of São Paulo, Graduate Program in Animal Nutrition and Production (PPGNPA)

${ }^{10}$ Federal University of Pelotas, Animal Science
} 


\section{Introduction}

Brazil is ranked fifth in global milk production, with 35.1 billion liters produced in 2018, and the intake of milk, on an industrial scale, was 24.3 billion liters in the same year. The per capita consumption of milk in Brazil is of 60 liters/inhabitant/year, while the consumption of dairy products totals 173 liters/inhabitant/year (EMBRAPA, 2018). To meet this demand, the dairy industry requires excellent quality raw materials, with proper yield, besides not affecting the industrial process (HANUŠ et al., 2018). Therefore, for the production of consumer-safe foods, the dairy processing industry must be aware of milk components, level of contamination and stability (SILVA et al., 2012).

Bovine milk is composed of lipids, carbohydrates, mineral proteins, and vitamins, and it is considered a nutritionally complete food for human consumption (CAPPOZZO et al., 2015; CHAVAN et al., 2016; O'SULLIVAN; COTTER, 2017). The presence of water in the milk, combined with the high $\mathrm{pH}$ nutritional compounds, are an environment conducive to microbial development, requiring the use of heat treatment (pasteurization or UHT - Ultra-high Temperature processing) to ensure food safety and increase the shelf life of the product (CLAEYS et al., 2013; MCAULEY et al., 2016). Milk must have adequate quality and hightemperature resistance, without coagulating, when subjected to these types of heat treatment; otherwise, issues of thermal stability may occur (LE et al., 2015). Some factors that are related to milk composition may affect thermal stability, such as milk proteins (mainly casein), lactose, acidity, urea and saline composition (calcium, citrates, and phosphates) (MURPHY et al., 2016). Other weighting factors regarding milk composition are cow age, lactation period, the incidence of mastitis and the animals' diet (CLAEYS et al., 2014).

In Brazil, the legislation requires technical regulation for products of animal origin, such as raw milk, in which the alcohol or alizarol stability test (alcoholic solution with alizarin $\mathrm{pH}$ indicator) is performed on the dairy farm to identify high bacterial contamination in milk samples, being mandatory to determine the acidity and the stability of the product before shipping it to the consumer market, regulated by normative instructions IN - 76 and IN - 77 (FAO, 1996; BRASIL, 2018).

According to Barros (2001), the alcohol test carried out in dairy farms determines the acceptance or rejection (in this case, the milk is discarded) of the product by the industry at the time of its collection. The rejected milk presents protein precipitation by the test due to the reduction of $\mathrm{pH}$ via lactose fermentation and lactic acid production because of the presence of microorganisms in the milk. However, the relationship between $\mathrm{pH}$, lactic acid and the microorganisms load may be influenced by the presence of psychrotrophic agents in the milk, which do not metabolize lactose into lactic acid, bringing about high bacterial counts that are not 
always attributed to acidity (SAMARŽIJA et al., 2012). The reduced stability of milk in the presence of alcohol testing leads to problems in equipment at the manufacturing step. Coagulation during pasteurization or UHT process results in obstruction and blockages in the process, as well as problems in the manufacture of creamy liqueurs, such as fat-plug. Besides, with emulsion, the instability of shelf life is reduced (RADFORD et al., 2004). Another not least issue that interferes with those alcohol testing results is the unstable non-acid milk syndrome (UNAM), which is unstable in alcohol testing without acidity of microbiological origin (TSIOULPAS, 2007; FAGNANI, 2016).

In countries such as Brazil, Uruguay, Cuba, Argentina, India, and South Africa, alcohol testing is still used by the dairy industry, in which this UNAM phenomenon is frequently detected. In other countries such as Australia, Canada, United States, New Zealand, and some European countries, alcohol testing has already been abolished as a safe and efficient practice in detecting stability problems because, in these countries, the milk quality is high. And it is different from Brazil regarding the degree of technification and knowledge of those technologies by farmers and even by the dairy industry (BATTAGLINI et al., 2013; MARTINS et al., 2015).

Unstable non-acid milk presents physicochemical changes in milk quality due to multifactorial causes, which are associated with metabolic, physiological and nutritional disorders, as well as determining factors for milk synthesis. The loss of casein stability present in the alcohol test is one of the biggest changes, resulting in positive precipitation without high acidity (above $18^{\circ} \mathrm{D}$ ) (MARQUES et al., 2007; ZANELA et al., 2009). UNAM is a problem that requires attention, as it leads to the condemnation and disposal of milk in the farm, giving rise to economic losses to the farmer, as well as to the industry, which no longer collects a larger volume of milk for processing.

Noting the increasing importance given to the quality of the raw material by the dairy industry, this review aimed to find, in the literature, evidences on the factors that interfere in the thermal stability of bovine milk and the use of alcohol testing in the dairy industry.

\section{Milk quality and its composition in Brazil}

Bovine milk is characterized as an emulsion of fat globules in suspension of casein micelles in the aqueous phase, with the presence of lactose molecules, whey proteins and solubilized minerals. It is basically composed of water $(87.3 \%)$, total solids $(12.7 \%)$, total proteins $(3.3 \%$ to $3.5 \%)$, fat (3.5\% to $3.8 \%)$, lactose $(4.9 \%)$ and minerals and vitamins $(0.8 \%)$ (CHANDRAKANT; SINGH, 2018). Some variations may occur, influenced by the animal breed (Table 1) (SORMOLI, 2013). Milk quality refers to characteristics that influence the nutritional 
value, yield, and safety of dairy products that are produced, being determined by composition, hygiene and safety aspects with nutritional, sensory and technological quality (MONARDES, 2004). For Marques, Fischer, and Zanela (2010), milk quality must present chemical, microbiological and organoleptic composition and a number of somatic cells that meet international quality requirements, being free of any kind of adulterants, disinfectants, and antibiotics.

Table 1 - Chemical composition of milk from different bovine breeds.

\begin{tabular}{lcccc}
\hline \multicolumn{1}{c}{ Breed } & Fat $(\%)$ & Protein $(\%)$ & Lactose $(\%)$ & $\begin{array}{c}\text { Dry Matter } \\
(\%)\end{array}$ \\
\hline Holstein & 3.5 & 3.1 & 4.9 & 12.2 \\
Jersey & 5.5 & 3.9 & 4.0 & 15.0 \\
Zebu & 4.9 & 3.9 & 5.1 & 14.7 \\
Brown Swiss & 4.0 & 3.6 & 5.0 & 13.3 \\
\hline
\end{tabular}

Adapted from Órdoñez et al. (2005); Gonzalez (2001).

According to reports by Tsenkova et al. (2001), the somatic cell count (SCC) acting on the secretion of milk indicates aspects of mammary gland health, being widely used as an indicator of subclinical mastitis and as a measure that determines the quality of the analyzed milk. Another important issue referred to SCC is that when its levels in the milk are high, there is a reduction in casein, fat and lactose concentrations in milk, increased enzymatic activity and reduced quality and yield of dairy products (REIS et al., 2013).

As for the nutritional factors of the animal, they cause problems regarding the composition of the milk, affecting its quality, because there is a need of paying extreme attention to the type of food provided, its availability, way of conservation and, above all, adjusting the diet according to the needs of the animals. Genetic factors (species and breed), environmental factors (stress, season, management), intrinsic factors of the animal (age, stage of lactation, number of lactations), extrinsic factors (health and bacterial contamination) are also responsible for the milk quality, all in which the search for stability within the production system must be constant (ZANELA et al., 2014).

Milk quality standards are controlled in Brazil by the Ministry of Agriculture, Livestock and Supply (MAPA), in which, in 2019, the normative instructions IN-76 and IN-77 came into force. IN-76 deals with the product's characteristics and quality in the industry, while IN-77 defines criteria for obtaining milk with quality, safe for the consumer, which ranges from the organization of the farm, its facilities, and equipment, until the training and qualification of those who are responsible for daily tasks, the systematic control of mastitis, brucellosis and 
tuberculosis (BRASIL, 2018). The minimum standards established for the industrial receiving of milk regarding its chemical composition are $3.0 \%$ of fat, $2.9 \%$ of protein and $8.4 \%$ of defatted dry extract. The maximum number of somatic cell count (SCC) is 500,000 cells $/ \mathrm{mL}^{-1}$ of milk, and the total bacterial count (TBC) is $300,000 \mathrm{CFU} / \mathrm{mL}^{-1}$ of milk. Regarding the physical characterization, milk must have a titratable acidity between 14 and $18{ }^{\circ} \mathrm{D}$ and must be stable in an alcoholic solution with at least $72{ }^{\circ} \mathrm{GL}$ of ethanol (BRASIL, 2018).

\section{Heat Stability of Milk (HSM)}

Milk stability is considered as the fundamental time for visual coagulation to occur at a given $\mathrm{pH}$ and temperature, and it is directly related to the ability of milk to resist coagulation at certain temperatures (LEITNER et al., 2016). The heat stability of milk is multifactorial, being punctually linked to its protein structure, more specifically in the casein fraction, which is largely responsible for the physical structure of milk (HANUŠ et al., 2018).

\section{Thermal Treatment}

The dairy industry in Brazil has, regarding heat treatment, a need for application, but its intensity should be measured not to cause damage to the quality of processed food. UHT (Ultra High Temperature) milk, known as long-life milk, is homogenized for 2 to 4 seconds at a temperature between $130{ }^{\circ} \mathrm{C}$ and $150{ }^{\circ} \mathrm{C}$ by a continuous flowing thermal process, and then it is immediately cooled to below $32{ }^{\circ} \mathrm{C}$ and packaged under aseptic conditions in sterile and hermetically sealed packaging (BRASIL, 1997). The heat treatment of milk is extremely intense and destroys opportunistic contaminating microbiotas, the pathogenic and sporulated ones, proving to the consumer to be a safe final product (HUPPERTZ, 2016). According to Fox's (1981) studies, milk, when subjected to heating, can be classified into five groups due to changes that precede coagulation: acid production, calcium phosphate precipitation, casein modifications, darkening reaction (Maillard) and interaction of sulfhydryl groups, including whey proteins or urea.

O'Connell \& Fox (2016) concluded, in their studies, that the effect of the temperature influences milk constituents, causing significant variations in both protein and salt balance. Warming and denaturation of soluble proteins are observed effects that give rise to the $\beta$ lactoglobulin/ $\kappa$-casein complex, resulting in physicochemical disorders of milk (HANUŠ et al., 2018). In saline equilibrium, calcium phosphate precipitation occurs in association with the micellar phase and the reduction of soluble inorganic calcium and phosphorus contents. This loss 
of salt balance due to warming is only moderately recovered due to the solubilization of colloidal calcium phosphate fractions (CHAVAN, SEHRAWAT, MISHRA, \& BHATT, 2016).

\section{Intrinsic factors that affect the heat stability of bovine milk}

\section{Casein}

Milk stability is due to the organization of caseins in micelles. Casein is one of the milk proteins and is synthesized in the epithelial cells of mammary gland and secreted in the form of micelle, and can be called phosphoproteins containing serine-linked phosphate radicals (P-se), present in several regions of the polypeptide chains, presenting more hydrophilic or more hydrophobic zones (amphipathic activity), being more susceptible to proteolysis (CHANDRAKANT; SINGH, 2018). The micelle represents $95 \%$ of the casein form in milk and are the main components responsible for maintaining the heat stability of milk (MURPHY et al., 2016).

Somewhat, all fractions of casein seem to be involved with the term stability (caseins $\alpha, \beta$, $\mathrm{K}$ and $\gamma$ ), especially K-casein, which, being on the surface of the micelle, interacts with other whey proteins and also with calcium, which promotes an electrostatic change, favoring the aggregation of casein molecules and facilitating their precipitation (O'CONNELL; FOX, 2016). To prevent precipitation of casein micelles, $\kappa$-casein plays an important role in stabilizing the micelle in the presence of calcium (CHANDRAKANT; SINGH, 2018). When water is added to milk or soluble calcium is decreased, casein stability increases because its micelle retains water equivalent to three times its weight, while maintaining stability (HUPPERTZ, 2016).

Another factor that impairs casein stability is the development of proteolytic psychrotrophic bacteria, which act at low temperatures $\left(0{ }^{\circ} \mathrm{C}\right.$ to $\left.15^{\circ} \mathrm{C}\right)$, producing thermostable enzymes that eventually act on K-casein and destabilize the milk stored in the cooler (FAGNANI, BELOTI; BATTAGLINI, 2014). According to Gaucher, Mollé, Gagnaire, \& Gaucheron (2008), the action of psychrotrophic protease enzymes occurs differently among fractions of milk proteins, with K-casein being the most susceptible to the action of these enzymes, whereas proteins of serum are resistant to protease attacks, as well as $\mathrm{pH}$ imbalances. Table 2, which is at the end of this research, shows the summary of some studies on casein behavior concerning milk thermal stability. 
Table 2 - Summary of studies of casein behavior in relation to milk thermal stability. ${ }^{a}$

\begin{tabular}{|c|c|c|}
\hline Experimental approach & Results & Reference \\
\hline $\begin{array}{l}\text { Lactation period } \\
\text { Two } 6 \text { weeks' periods. Period } 1 \\
\text { cows were in mid lactation. Period } \\
2 \text { cows were in late lactation. }\end{array}$ & $\begin{array}{l}\text { Milk samples in mid lactation were more } \\
\text { thermally stable than in late lactation. } \\
\text { Milk produced during late lactation has a } \\
\text { higher plasmin activity, promoting hydrolysis } \\
\text { of casein, which may contribute to reduced } \\
\text { thermal stability. }\end{array}$ & O'Connell et al. (2017) \\
\hline $\begin{array}{l}\text { Plasmin } \\
\text { It was added } 6 \mathrm{mgL}^{-1} \text { of plasmin to } \\
\text { examined its effect on the heat } \\
\text { stability of raw, pre-heated, serum } \\
\text { protein-free or concentrated skim } \\
\text { milk. } \\
\text { Samples were incubated at } 37^{\circ} \mathrm{C} \text { for } \\
0,3,7 \text { and } 16 \text { days, after which } \\
\text { samples were analysed for plasmin } \\
\text { activity, plasminogen-derived } \\
\text { activity and proteolysis. }\end{array}$ & $\begin{array}{l}\text { Plasmin activity markedly affected the heat } \\
\text { stability-pH profile of skim milk and serum } \\
\text { protein-free milk, apparently by altering the } \\
\text { properties of the casein micelles. } \\
\text { Plasmin-induced casein proteolysis was } \\
\text { observed and the degree of hydrolysis was } \\
\text { primarily correlated with plasmin activity, } \\
\text { which results in gradual loss of colloidal } \\
\text { stability of the micelles. }\end{array}$ & Crudden et al. (2005) \\
\hline $\begin{array}{l}\text { Seasonal variation } \\
\text { Milk samples were collected } \\
\text { monthly from a mixed-herd of } \\
\text { spring- and autumn-calving cows } \\
\text { during a year. }\end{array}$ & $\begin{array}{l}\text { Season did not influence the heat stability } \\
\text { characteristics of the milk, however ethanol } \\
\text { stability of autumn milk or winter milk at } \mathrm{pH} \\
7.0 \text { was lower than that of spring or summer } \\
\text { milk. }\end{array}$ & Lin et al. (2017) \\
\hline $\begin{array}{l}\text { Transglutaminase } \\
\text { Heat-induced coagulation of } \\
\text { unconcentrated reconstituted skim } \\
\text { milk was determined after } \\
\text { incubation with transglutaminase. }\end{array}$ & $\begin{array}{l}\text { Treatment with transglutaminase reduced heat } \\
\text { stability of milk at } \mathrm{pH}<6.6 \text {. }\end{array}$ & Huppertz (2013) \\
\hline $\begin{array}{l}\mathrm{pH} \\
\text { Fresh bulk raw milk was acidified } \\
\text { with } \mathrm{HCl} \text { at } \mathrm{pH} 6.4(\mathrm{~T} 2), 6.1(\mathrm{~T} 3) \text {, } \\
5.8(\mathrm{~T} 4) \text { and } 5.5 \text { (T5), viewing } \\
\text { analyzed in terms of casein } \\
\text { molecules. Control milk suspension } \\
\text { (T1) was prepared in the same } \\
\text { conditions. }\end{array}$ & $\begin{array}{l}\text { The obtained suspensions were progressively } \\
\text { demineralized and partial dissociations of } \\
\text { casein micelles were observed. Suspensions } \\
\text { T1 and T2 were more stable than T3 which } \\
\text { have an intermediate stability, and T4 and T5 } \\
\text { which were the most unstable. These decreases } \\
\text { of stability were related to the presence of } \\
\text { small casein particles and the quantitative } \\
\text { reduction of casein micelles. }\end{array}$ & Silva et al. (2013) \\
\hline $\begin{array}{l}\text { Contamination } \\
\text { Fresh bulk milk was microfiltrated } \\
\text { and then divided into two parts: one } \\
\text { served as the control milk and the } \\
\text { second was incubated for } 2 \text { hours at } \\
4^{\circ} \mathrm{C} \text { in the presence of the } \\
\text { psychrotrophic bacteria } \\
\text { Pseudomonas fluorescens. } \\
\text { The heat-stable protease Ser } 2 \text { is } \\
\text { secreted by the species Serrati } \\
\text { liquefaciens, a psychrotrophic } \\
\text { bacteria frequently found in raw } \\
\text { milk. The enzyme was purified and } \\
\text { added to microfiltered raw milk } \\
\text { before UHT treatment. }\end{array}$ & $\begin{array}{l}\text { P. fluorescens induced instability in the } \\
\text { corresponding UHT milk during storage. This } \\
\text { instability was detected by the presence of a } \\
\text { sediment, a low value in the phosphate test and } \\
\text { the formation of aggregates. These } \\
\text { macroscopic instabilities were related to } \\
\text { decreases in the negative charge and hydration } \\
\text { of casein micelles. } \\
\text { A visual destabilization appeared after } 8 \text { days } \\
\text { of storage with the presence of sediment. This } \\
\text { confirmed that the presence of the protease } \\
\text { Ser } 2 \text { in raw milk can be one of the main causes } \\
\text { of UHT milk destabilization. }\end{array}$ & Baglinière et al. (2017) \\
\hline
\end{tabular}

${ }^{a}$ Abbreviations are: $\mathrm{HCl}$, hydrochloric acid; UHT, ultra-high temperature.

\section{pH and Acidity of Milk}


Bovine milk has natural acidity formed from its acids and chemical composition, being considered normal levels of titratable acidity between 14 and $18^{\circ} \mathrm{D}$, and $\mathrm{pH}$ between 6.6 and 6.8. (BRASIL, 2011). Some factors have direct involvement in the acidity of bovine milk, such as lactation period, inflammatory and infectious processes of the mammary gland, endogenous and exogenous enzymatic action, with minimal and distinct changes in the heat stability of milk (BARBOSA et al., 2008). The maximum point considered for milk stability is close to a $\mathrm{pH}$ of 6.7 due to the aggregation of whey proteins (albumin and globulin) with the micellar surface, but when the $\mathrm{pH}$ exceeds 6.9 , there is a dissociation of whey proteins and also K-casein, reducing milk stability (SINGH, 2004; O'CONNELL; FOX, 2016). Milk heating processes interfere with its $\mathrm{pH}$, given that lactose is broken down into organic acids, leading to a $\mathrm{pH}$ reduction and resulting in displacement of the maximum milk stability range (CHANDRAKANT; SINGH, 2018).

Casein is highly sensitive to acidity, as when milk becomes acidic, its positive ions neutralize the negative charge of casein, thus decreasing the repulsive force between molecules, favoring the association and making them less heat-stable (FOX; BRODKORB, 2008). By the time its isoelectric point is reached ( $\mathrm{pH} 4.6)$, in other words, when total neutralization of negative casein charges occurs, the micelle flocculates and unite retaining fluid (serum). At the same moment, the contraction of the casein micelle begins, expelling the serum, causing dehydration and calcium output from the micelle (O'CONNELL; FOX, 2016). An acidic pH (below 6.5) reduces the ionic strength that maintains the micellar structure, shifting calcium from the colloidal phase to the soluble one, causing an increase in ionic calcium (BELOTI, 2015).

\section{Ionic Calcium}

Ionic calcium has a high degree of importance, since it is considered the main factor of interference in milk stability, acting both in heat and ethanol stabilities, and it is distributed in three phases: colloidal, soluble and ionic (O’CONNELL; FOX, 2016). Approximately $70 \%$ of the calcium is in the colloidal phase and in the form of calcium phosphate bounded to casein micelles. The remaining $30 \%$ is in the form of solution, distributed among bonds with citrates and phosphates or as free ions (FAGNANI et al., 2014). The presence of salt in milk reduces the ability of casein to maintain its physical structure, and the mineral salt saline balance between both phases (colloidal and soluble) must be preserved. However, when an imbalance occurs, there will always have compensation, resulting in an increase in ionic calcium, which goes from the soluble to the colloidal phase, causing milk instability (HOLT, 2004).

Ion calcium levels are affected by various aspects, such as temperature, $\mathrm{pH}$, milk storage time, while concerning animal factors, are affected by lactation time (cows in early and late 
lactation have higher levels of ionic calcium), the time between the collection of samples and measurement of calcium (levels may increase up to eight hours after collection) (BARBOSA et al., 2008). Changes in $\mathrm{pH}$ directly influence calcium mobilization from one phase to another. Reductions in $\mathrm{pH}$ cause calcium displacement from the colloidal phase to the soluble one, increasing ionic calcium (RENHE et al., 2018). Increased levels of ionic calcium in milk tend to increase ionic strength by binding ions to protein-charged groups, leading to reduced electrostatic repulsion that favors protein agglutination and reduces the stability of casein, stabilizing salts to maintain the integrity of the micelle (CHANDRAKANT; SINGH, 2018). When this type of electrostatic repulsion occurs, it leads to a micellar breakdown, which is a result of increased micelle hydrophobicity. When the level of calcium is reduced, there is an increase of negative charges of micelles, intensifying the repulsion between them, making precipitation difficult (BELOTI, 2015). This can be explained by the sensitivity of casein to calcium, as phosphoserine residues agglomerate and are negatively charged and bind to calcium, affecting the stability of micelle (CHANDRAKANT; SINGH, 2018).

\section{Stabilizing Salts (Citrates and Phosphates)}

The mobility of milk salts in their soluble and colloidal phases establish direct equilibrium relationships with the stability of bovine milk, mainly due to the increase of calcium in the soluble phase and the decrease of phosphate and citrate activity (HUPPERTZ, 2016). According to Fox, (1981) about $94 \%$ of citrate is found in the soluble phase, $85 \%$ of which is associated with calcium and magnesium, but only $6 \%$ is represented in the colloidal form, which contributes to the union of casein micelles, being synthesized inside the epithelial cells of the mammary alveolus (SILVA, 2012).

Warming milk at certain temperatures results in the loss of stability of casein micelles due to the interference on the saline balance of milk so that colloidal calcium and phosphate (before bounding casein) will separate from it and precipitate into the tricalcium phosphate form (BELOTI, 2015). Therefore, the dairy industry that uses UHT treatment in Brazil adds citrates and phosphates to milk, since they can increase the stability of casein, reducing its tendency to aggregation, coagulation, and precipitation (O'CONNELL; FOX, 2016). Animal feed is directly correlated with citrate levels, as forages are its main sources. Low bulk diets determine low citrate yields (SILVA, 2004). Phosphate establishes a reduction in ionic calcium in milk, thus ensuring increased stability, but its effect is short-lived compared to citrate, as it remains longer in the soluble phase (MELETHARAYIL et al., 2018). 
Phosphates are divided into two groups in casein micelle - casein-bound covalent organic phosphate as part of the side chains of phosphoserine residues; and inorganic phosphate, in the form of calcium phosphate crystals that are displaced from the micelle by acidification and whose interaction has a more ionic characteristic than the covalent one (MCMAHON, 2010). The colloidal calcium phosphate bonds with the $\alpha, \beta$ and $\kappa-\mathrm{CN}$ fractions, which are responsible for micelle stability and are called crosslinking bonds, which manifest themselves as an agent that neutralizes residues of phosphorine, positively charging it, binding to negative sites by micellar calcium phosphate (GAUCHERON, 2005). This same author states that colloidal calcium bonds are broken when the milk is in an acid medium, being irreversible even if the $\mathrm{pH}$ is stabilized. All inorganic phosphate is solubilized at $\mathrm{pH}$ 5.2, with the destruction of inorganic micellar calcium phosphate, that is, calcium that is bound to inorganic phosphate and phosphoserine. At a $\mathrm{pH}$ of 3.5 calcium is fully solubilized (BELOTI, 2015). If there is no phosphate to remove soluble calcium, even at high $\mathrm{pH}$, milk shows reduced stability against alcohol testing (FAGNANI et al., 2016).

\section{Seroproteins in Milk}

Certain factors that interfere with the way milk becomes unstable to heat treatment are linked to kappa-casein $(\mathrm{k}-\mathrm{CN})$ and soluble beta-lactoglobulin $(\beta-\mathrm{Lg})$, as seroproteins end up denatured when heated and react with k-casein causing instability (SINGH, 2004; ANEMA \& LI, 2003). The issue is because beta-lactoglobulin $(\beta-\mathrm{Lg})$ is a thermolabile seroprotein, from its arrangement in sulfhydryl groups combined with its calcium sequestration capacity at a certain $\mathrm{pH}$. Dissociation of $\beta$ - $\mathrm{Lg}$ begins at temperatures between $30^{\circ} \mathrm{C}$ and $55^{\circ} \mathrm{C}$, reaching its peak at 80 ${ }^{\circ} \mathrm{C}$ and $\mathrm{pH} 6.5$ or $60{ }^{\circ} \mathrm{C}$ and $\mathrm{pH} 8.0$, causing denaturation, which is one of the reasons for sedimentation problems in UHT milk equipment faced by the dairy industry in Brazil, requiring the use of stabilizers in the process (BELOTI, 2015).

\section{Urea Nitrogen in Milk}

High milk urea levels increase milk urea stability due to reduced acidity or transformation of urea into cyanate, which tends to react in the presence of protein increasing negative micelle charges, thus providing higher repulsion force, increasing thermal stability of milk (MARTINS et al., 2015).

$\mathrm{N}$-urea levels in milk are directly linked to the feed that the animals are given to, always referred to the protein composition of the diet, in which a sample with a value above $3.2 \%$ of protein should not exceed $18 \mathrm{mg} / \mathrm{dL}^{-1}$ of urea nitrogen. Higher levels indicate an excess of 
degradable protein in the diet or a soluble carbohydrate deficit, even resulting in low lactose levels in the milk (PEREZ Jr., 2001; MARQUES et al., 2010).

As for the cheese industry, this increase in milk urea can become a problem, since it tends to reduce the clotting time, and the protein responsible for cheese mass is replaced by $\mathrm{N}$-urea (BELOTI, 2015).

\section{Lactose of Milk}

Being the main carbohydrate in milk, lactose determines its volume by representing $50 \%$ of milk osmotic pressure, associated with sodium, chlorine and potassium ions in the mammary gland. Lactose drags about ten times its weight in water, and an increase in lactose concentration above $50 \%$ of normal results in instability of type A milk at $\mathrm{pH} 6.4$ to 6.7 and carries the minimum stability point to more alkaline $\mathrm{pH}$ values (SINGH, 2004). The addition of lactose to milk negatively interferes with its stability due to the increased rate of $\mathrm{pH}$ reduction by the transformation of lactose into lactic acid when milk is outside the minimum stability $\mathrm{pH}$ range (6.6 to 6.8), where the decrease in stability is also due to the increase in ionic calcium concentration, taking into account the temperature conditions in which this milk is stored (CHAVEZ et al., 2004).

\section{Bovine Milk Temperature}

Some aspects of milk stability are related to the temperature at which milk is subjected. Fagnani, Battaglini, Beloti, Urbano, \& Bronzol (2016) pointed out the reduction of k-casein fraction stability with ionic calcium content due to the cooling time of the milk sample. According to the same authors, cooling causes changes and disorganization in saline balance (P and $\mathrm{Ca}$ ) between micelles and soluble phase, increasing serum calcium, phosphorus and casein concentrations, and $\mathrm{pH}$ increases rapidly $\left(0.3-0.4 \mathrm{pH}\right.$ unit between 38 and $\left.6{ }^{\circ} \mathrm{C}\right)$. Micellar casein at $20{ }^{\circ} \mathrm{C}$ represents 93 to $95 \%$ of the total milk casein, but if refrigerated at $2{ }^{\circ} \mathrm{C}$ becomes 80 to $85 \%$, causing an imbalance between caseins and directing the soluble phase, reducing the average diameter of the micelles (HUPPERTZ, 2016). Milk preheating alters milk stability in the $\mathrm{pH}$ range from 6.4 to 6.8 due to changes in the system's ionic balance by temperature-induced calcium phosphate precipitation (FAGNANI et al., 2014).

These events directly affect the dairy industry, as they result in changes in technological properties, such as increased coagulation time, changes in curd consistency and reduced yield of cheese production up to $10 \%$. A possible solution to restore its properties is the use of prematuration, adding calcium chloride $\left(\mathrm{CaCl}_{2}\right)$ mixture for initial $\mathrm{pH}$ adjustment (BELOTI, 2015). 


\section{Plasmin}

Bovine milk contains the complete plasmid system: plasmin, plasminogen, plasmin activators (PAs), and plasmin and PAs inhibitors (KELLY; MCSWEENEY, 2003). Plasminogen is activated in plasmin by PAs, which are divided into two main classes, the urokinase (u-PA), associated with somatic cells, and the tissues (t-PA), associated with casein micelles (WHITE et $a l ., 1995)$. Unlike other structures of the plasmid system, plasmin and PAs inhibitors occur in the serum phase of milk (WEBER; NIELSEN, 1991).

Plasmin is a technologically important structure in bovine milk, as it reduces the quality of dairy products. $\alpha_{\mathrm{s} 1}$-casein is susceptible to plasmin proteolysis, while $\alpha_{\mathrm{s} 2}$-casein and $\beta$-casein are used as substrates. Plasmin activity drives effects on milk and dairy products, such as shorter rennet coagulation time, reduced curd firmness, lower cheese yield, UHT milk gelation over time, development of bitter milk flavors and degradation of casein-based products during storage (MARA et al., 1998; CRUDDEN, 2005).

\section{Extrinsic factors that affect the heat stability of bovine milk}

\section{Lactation Period}

The lactation period of the animal has a direct influence on the heat stability of milk due to changes in its constituents since during lactation the potassium and lactose proportions are constantly decreasing, peaking at the beginning and decreasing until the end of lactation. direct binding to the cow's nutritional factor. For chlorides and sodium, levels start to low and rise, peaking at the end of lactation (O'CONNELL; FOX, 2016). As a consequence of these occurrences, there is a protein concentration in the milk, increasing the formation of the $\beta$ Lactoglobulin/א-casein complex, and calcium and phosphorus follow the same pattern, in which ionic calcium has an increase in the beginning and end of lactation, interfering in the stability of milk (BARROS, 2002).

\section{Herd Nutrition}

Another factor directly linked to milk stability is the feeding that lactating animals receive, in which the compensatory capacity of the animal's organism should reduce the effects of nutritional imbalances on milk stability. Feed restriction of animals from alcohol test is negatively seen in numerous studies in the literature (GABBI et al., 2016) (will be approached in item 4.2.3), and a small number of studies that elucidate the relationship between nutrition and the heat stability of milk (ZANELA et al., 2014). According to Murphy, Martin, Barbano, \& Wiedmann, (2016), low serum glucose levels would be the triggering factor of milk instability, 
which is confirmed by the reduced lactose levels. Another factor is that diets that lead to lower intake of citric acid precursors will determine a lower level of produced citrate, which strongly interferes with milk stability (ZANELA et al., 2009).

\section{Bovine Breed}

High-production Holstein cows are more likely to show changes referred to the heat stability of milk (PONCE; HERNANDES, 2001). This breed has a lower frequency of allele B for k-casein when compared to Jersey cows. According to the studies of Robitaille, Britten, \& Petitclerc, (2001) with the expression of B alleles greater than alleles A has, there is a positive imprint to ensure greater milk stability against alcohol testing because it needs higher concentrations of ethanol to produce any type of instability in milk proteins.

Regarding breeds with crossbreed Bos taurus taurus vs Bos taurus indicus, in a study carried out by Botaro et al. (2009), the milk produced by Holstein cows was more stable to the alcohol test when compared to Girolando cows, besides presenting higher presence of B allele than the crossbred milk.

\section{Mastitis, Somatic Cell Count (SCC) and Total Bacterial Count (TBC)}

Animal health is directly related to the thermal stability of milk. Animals with mastitis elevate the passage of sodium chloride directly from blood to milk, causing disorganization of the salt balance. Mastitic milk is three times more likely to be unstable when compared to healthy cow milk, and the increase in milk $\mathrm{pH}$ is responsible for this occurrence, due to the greater permeability of the mammary epithelium to small particles and ions, as mastitis modifies the vascular permeability of milk-secreting cells, ( $\mathrm{Na}, \mathrm{Cl}, \mathrm{P}$ and $\mathrm{K}$ ) (FAGNANI et al., 2014). Mastitis, when established in animals, tends to elevate undesirable characteristics of milk, such as proteolytic enzymes, salts, and rancidity and reduces desirable protein, fat and lactose levels, as well as cheese production and heat stability (OLIVEIRA et al., 2013). The reduction in lactose concentration caused by mastitis due to breast tissue damage decreases the capacity of synthesis by the glandular epithelium, affecting the volume of milk produced (LEITNER et al., 2016).

Milk with high somatic cell index (SCC) has high enzymatic activity, with increased proteolysis and lipolysis in the udder, both before milking and after the animal is milked. Somatic cell lysosomes are provided with proteolytic enzymes, such as cathepsin D, which from K-casein can produce caseinmacropeptide, which in high concentration ends up causing milk coagulation (HUPPERTZ, 2016). 
High levels of total bacterial count (TBC) interfere in the composition of bovine milk, causing an increase in the concentration and passage of blood proteins and a reduction in lactose (BUENO, 2008). When milk TBC increases, there is also an increase in the action of proteolytic enzymes, which will modify the structure of casein micelles and reduce the repulsion capacity between them, generating heat stability disorders (SILVA, 2004). When we talk about levels of SCC and TBC, we need to emphasize that they will not always be correlated, because the microorganisms have a great reproductive capacity, which may be a reflection of the mastitis scenarios or poor quality of the water used in the hygiene of the utensils. Or even failure of the milk cooling system (RAMIRES et al., 2009; WINK; THALER NETO, 2009).

\section{Alcohol/Alizarol Test in Dairy Industry}

In the late nineteenth century, one of the main problems in the dairy industry was the uncooled milk that turned sour. The researchers of that time sought to solve this problem through a detection method of this fermented milk. A German researcher called Martinn, concluded in his experiments, in 1890, that by mixing equal parts of milk and alcohol, he could find acidity of microbiological origin. In the following years, the researcher Wilhelm Morres, in 1910, added to the test a color indicator, the alizarin dye (able to infer milk pH by colorimetry). Thus, the first milk quality test was created, providing safety to the industry, since if the tested milk formed lumps (coagulation) it would be sour and could not be industrialized (DEETH; LEWIS, 2017). The test of alcohol or alizarol was of great value to the world dairy industry because it made it possible to prevent acidic milk, such as colostrum or mastic milk from being processed, thereby reducing quality problems and coagulation in the heating plates of the dairy pasteurizer. Consequently, 1930 brought with it the best test to measure the thermal resistance of milk, because, by logic, if it coagulated in alizarol the same would happen in the pasteurizer. The following year, the reliability of the alcohol test was cast in doubt by Ramsdell, who concluded that no researcher could prove that this test was reliable in determining whether or not milk could withstand heating. Almost two decades later, Davis and White (1956) found no relationship between thermal stability and ethanol stability, suggesting that the thermal stability of milk is not only related to bacterial acidity, but other factors interfere in protein stability.

Nowadays, the first test that milk is subjected to after being milked and properly cooled is still the alcohol or alizarol test. Its application is done in the dairy farm, being a decisive instrument for quality milk approval and subsequent charging for dairy (ZANELA; RIBEIRO, 2018). This test evaluates the stability of milk proteins, which, when subjected to the dehydration caused by alcohol, is possible to estimate the resistance of milk to heat treatment in the industry, since milk with low hygienic quality during its production may present reduction of $\mathrm{pH}$ by 
lactose fermentation in lactic acid, thus resulting in increased protein instability (OMOARUKHE et al., 2010). One reason why this test is still widely used in some Latin American countries, in Africa, and the Far East by the dairy industry is because of its low cost coupled with the speed and simplicity of execution in regions with large number of low technological dairy farms (KASSA et al., 2013; HORNE, 2015; RATHNAYAKE et al., 2016).

Alcohol test is regulated in Brazil by the Industrial and Sanitary Inspection of Animal Products (Riispoa) since 1952. In 2002, the country introduced the National Milk Quality Improvement Program, supported by Normative Instruction No. 51 (BRASIL, 2002) of the Ministry of Agriculture, Livestock and Supply (MAPA). In 2011, the NI-51 was replaced by the NI-62 (BRASIL, 2011). Nowadays, the national legislation in force is NI-76 and NI-77, which establishes technical regulations of milk production, quality, collection and transport to the industry, where specifically NI-76 has parameters from production to reception in the industry, and NI-77 is responsible for the criteria for approving it into the industry until it is shipped (BRASIL, 2018). According to NI-76, moments before the milk is loaded on the farm, it must be shaken before the alcohol test (with a minimum concentration of $72{ }^{\circ} \mathrm{GL}$ ) and must be stable to the test (negative result). However, graduations of 76; 78 and up to $82{ }^{\circ} \mathrm{GL}$ of alcohol have been used by various industries, hoping to select better quality milk.

The alcohol test consists of mixing equal parts of milk and alcohol in the salut acidimeter (Figure 1). It is a way to evaluate the formation of clots or lumps in the milk, since the added ethanol causes changes in the K-casein layer, reducing micellar charge and calcium phosphate precipitation, occurring coagulation (STUMPF et al., 2013). In general, with this addition of alcohol to milk, there is a reduction of the dielectric constant of the medium, providing interaction between charges on the most superficial part of casein, decreasing the negative micellar charges and their repulsion force, promoting coagulation, which means that alcohol neutralizes the negative charges of milk proteins.

Figure 1. Acidimiter of salut (ethanol pistol) used to perform the test.

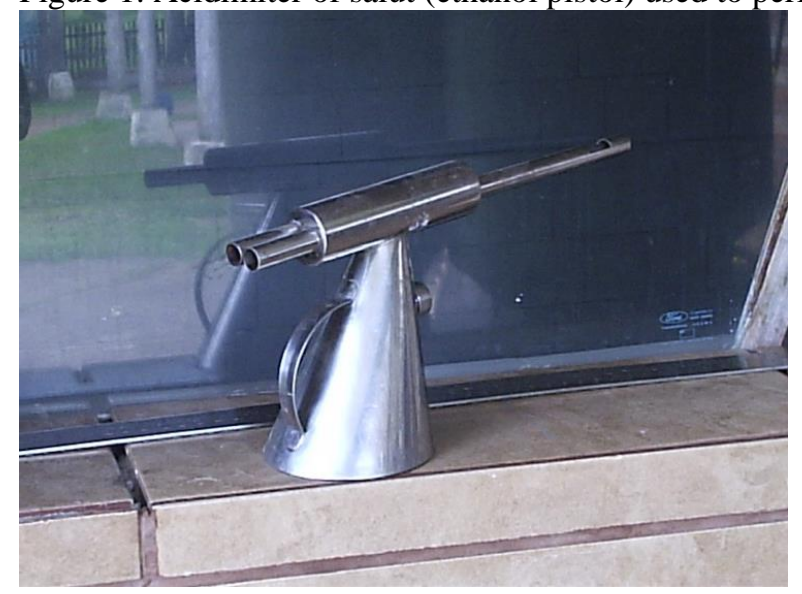

Photo: ZANELA; RIBEIRO (2018). 
Milk is considered stable when there is no precipitation (Figure 2), but when the result is positive to the alcohol test, the carrier rejects it, not collecting it, causing damage to both the farm and the industry that has reduced its volume milk intake.

Figure 2 Stable milk on the left, unstable milk on the right with clots.

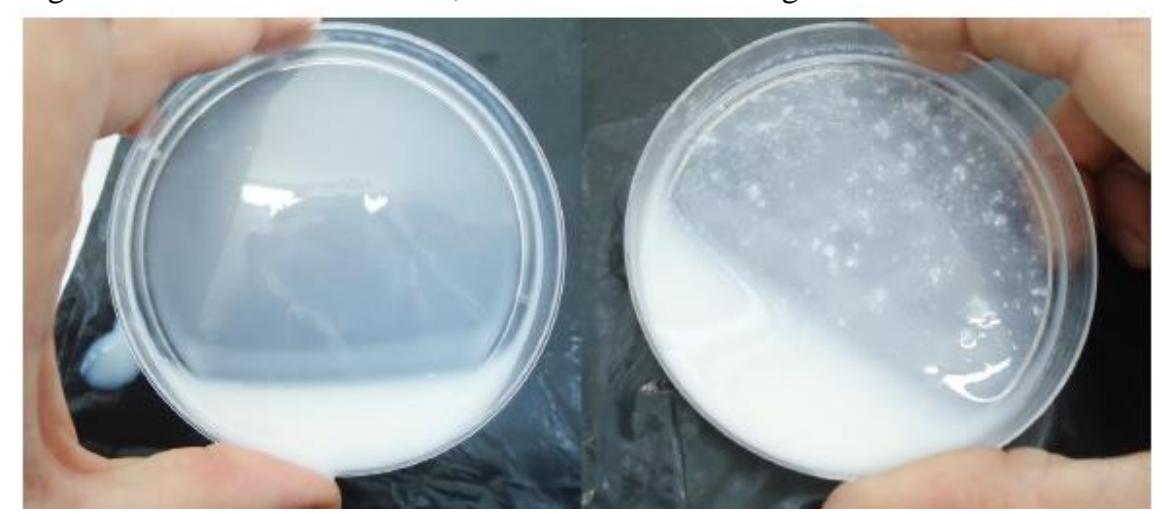

Photo: ZANELA; RIBEIRO (2018).

The alcohol test with alizarol (Figure 3) has the presence of the alizarin coloring, which reacts by changing color according to the $\mathrm{pH}$ in milk, allowing simultaneous observation of casein flocculation and color turning due to $\mathrm{pH}$ change. It consists of mixing in a test tube $2 \mathrm{~mL}$ of milk, $2 \mathrm{~mL}$ of $0.2 \%$ alizarin coloring and $0.1 \%$ of alcohol (TRONCO, 2013). When the pH is too acidic or basic, the change in color is easily noticed, otherwise, when it is in the normal $\mathrm{pH}$ range (6.6 to 6.8), the change in color is small, causing doubts and uncertainty in the evaluation of the results (ZANELA; RIBEIRO, 2018).

Figure 3 Ethanol test with alizarin.

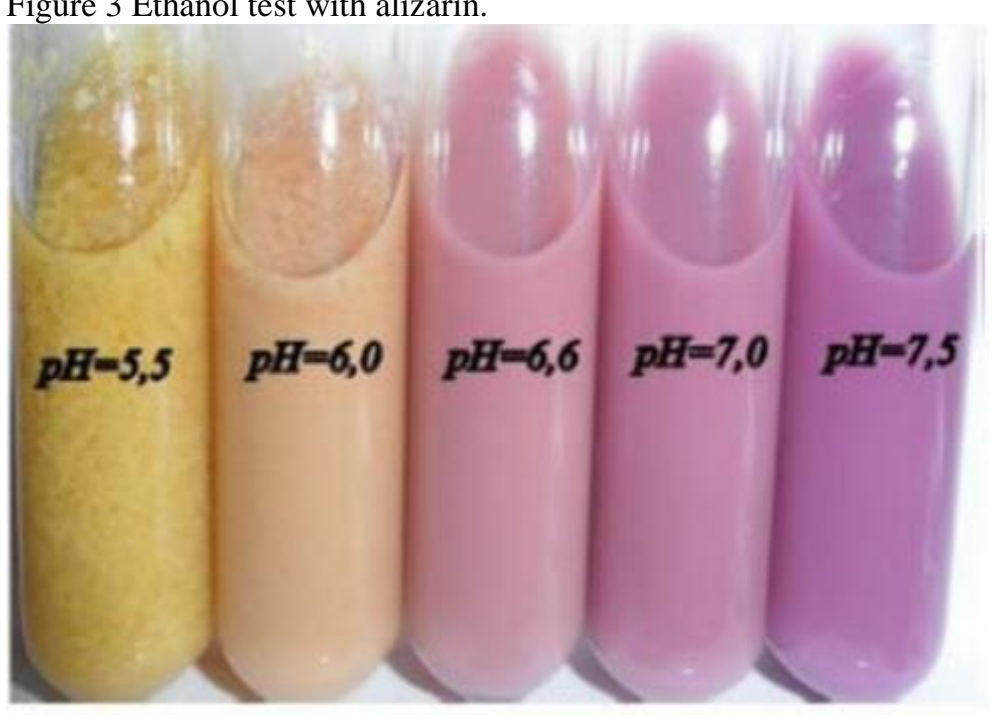

Photo: SANTOS; SILVA (2013).

The $\mathrm{pH}$ of the alcoholic solution used in the alcohol test may bring false-positive results if this parameter is not adjusted to near neutrality. Vizzotto et al. (2012) evaluated alcoholic Nucleus Animalim, v.12, n.2, nov. 2020 
solutions with ethanol concentration ranging from 68 to $92{ }^{\circ} \mathrm{GL}$ without $\mathrm{pH}$ adjusted and alcoholic solutions with $\mathrm{pH}$ adjusted (close to neutrality: 6.9 to 7.1 ) at the same concentrations. The authors observed that extremes (both low and high $\mathrm{pH}$ ) increased the frequency of positive samples over the adjusted solution. Another key issue in this test is the need to dilute alcohol to the correct concentration (volume/volume) and maintain this concentration until it is used, as a slight elevation of $1-2{ }^{\circ} \mathrm{GL}$ can produce quite different results. This fact explains why the results using $72{ }^{\circ} \mathrm{GL}$ alcohol is different from those using $74{ }^{\circ} \mathrm{GL}$ in the alcohol test (TRONCO, 2013).

When milk is considered normal without coagulation ( $\mathrm{pH} 6.6$ around neutrality), it acquired a reddish brick color (titratable acidity 14 to $18^{\circ} \mathrm{D}$ ). Milk samples with $\mathrm{pH} 5.5$ and 6.0 are highly acidic (above $21^{\circ} \mathrm{D}$ ) and are yellowish with coagulation. However, milk samples with high $\mathrm{pH}, 7.0$ to 7.5 (alkaline milk) are violet and purple. This correlation of $\mathrm{pH}$ and visually made colors can be misjudged between analyzes, damaging the dairy sector.

\section{Relation Between Heat and Ethanol Stability of Milk}

Industry in this test uses the alcohol concentration proportional to the rigor, with which it is desired to subject the milk to heat treatment in the processing industry, so coagulation tends to occur due to high acidity or saline imbalance when promoting the destabilization of micelles by alcohol. According to Tronco (2013), the higher the alcohol concentration, the better the product's thermostability and the better the milk conservation conditions. However, according to the studies by Machado, Fischer, Stumpf and Stivanin (2017), this correlation of increased alcohol content and increased heat resistance is not true. This correlation was widely questioned by authors seeking to assess whether the alcohol test could measure heat resistance of milk, but they have always come to low correlations, making this prediction uncertain (CHEN et al., 2014; HORNE, 2016; DEETH; LEWIS, 2017). During the heating process, a series of chemical changes occur, generating basic differences between the thermal stability of milk and the stability of alcohol, where seroproteins act on the stability of milk, forming the $\beta$-lactoglobulin/ $/$-casein complex, while $\mathrm{pH}$ interferes over calcium composition in different phases of the alcohol test (CHRAMOSTOVÁ et al., 2016). Horne and Muir (1990), when comparing the heat stability of milk compared to the alcohol test, found similarities between the methods in the $\mathrm{pH}$ adjustment and responded, at least qualitatively, in the same way to the increase or decrease of available calcium. Negri, Chavez, Taverna, Roberts, and Speranza (2001), when evaluating alcohol-stable milk samples at $78^{\circ} \mathrm{GL}$, submitted to heat stability test and presented longer coagulation time than alcohol-unstable milk samples at $72^{\circ} \mathrm{GL}$. 
Alcohol test, however, has shown positive results in milk with acceptable $\mathrm{pH}$ and acidity values ( $\mathrm{pH}$ of 6.6 to 6.8 and/or titratable acidity of 14 to $18{ }^{\circ} \mathrm{D}$ ) and $\mathrm{SCC}$ and $\mathrm{TBC}$ within the appropriate values (COSTABEL et al., 2009). According to Oliveira et al. (2011), $40 \%$ to $50 \%$ of milk samples presenting acidity within the acceptable values, precipitate in the alcohol test, being the farm penalized. Studies conducted by Molina, González, Brito, Carrillo, and Pinto, (2001) and Silva et al. (2012) demonstrated that the progressive increase in alcohol content increased the number of positive samples of milk to the alcohol test. Evaluating these events, the way the alcohol test is used by the industry should be reevaluated, as it ends up penalizing the farm with false-positive results.

These results are due to a confounding factor called Unstable Non-Acid Milk (UNAM), which is unstable in alizarol (lumps) but not acid in the Dornic acidity test, which measures the amount of lactic acid from bacteria. One way for the carrier to eliminate the false positive doubt is to boil the milk on the farm if it is not coagulating it is probably UNAM, which can be interpreted in the industry platform with the Dornic acidity result (14 and $\left.18^{\circ} \mathrm{D}\right)$. These facts call into question the reliability of alcohol test and draw our attention to the fact that perhaps it is time to abolish this method as a good raw material classifier for the dairy industry, following examples from European and North American countries.

\section{Unstable Non-Acid Milk (UNAM) Facing Alcohol Test}

Unstable Non-Acid Milk (UNAM) is termed as a change in milk quality resulting from multifactorial imbalances within the production system (ZANELA; RIBEIRO, 2018). Loss of casein stability on alcohol test is one of the main variations with false-positive results, with no evidence of high acidity (above $18{ }^{\circ} \mathrm{D}$ ), followed by physicochemical changes in milk, such as saline imbalance and proportion of divalent cations. (CHAVEZ et al., 2004). Because they are unaware of this UNAM factor, many farmers end up discarding this positive milk to the alcohol test, as they associate it with acid milk, causing damage to both the farm and the industry, which loses in raw material uptake. The alcohol concentration used at the time of testing is one of the key points for triggering UNAM. IN-76 states that milk should be stable to alcohol/alizarol at a minimum concentration of $72{ }^{\circ} \mathrm{GL}$ (BRASIL, 2018). However, the dairy industries have increased the level of this concentration, using up to $82 \%$ alcohol content, causing a reduction in the normal levels of acidity of milk, that is, exerting more radically its dehydrating action. Thus, a milk that passed the alcohol test with an alcohol content of $72{ }^{\circ} \mathrm{GL}$ could not withstand an alcohol concentration of 74 or $78^{\circ} \mathrm{GL}$ while maintaining the same titratable acidity of $18^{\circ} \mathrm{D}$.

The earliest reports of UNAM around the world were cited in the literature in countries such as Japan (YOSHIDA, 1980), Italy (PECORARI et al., 1984), Iran (SOBHANI et al., 1998), 
Cuba (PONCE, 2001), Uruguay (BARROS et al., 1999), Argentina (NEGRI et al., 2001), Brazil (DONATELE et al., 2003; MARQUES et al, 2007; ZANELA et al, 2009; ROMA Jr, 2007; LOPES, 2008, OLIVEIRA et al., 2013; WERNCKE et al., 2016). In Brazil, studies making use of diagnosis of UNAM began to be carried out at EMBRAPA in 2002, where in the Southern region of the country, Zanela et al. (2006) evaluated occurrences of UNAM, and 3,353 samples of milk were analyzed for alcohol test $\left(76^{\circ} \mathrm{GL}\right)$ and titratable acidity. According to the results, the vast majority $(72.2 \%)$ of the samples were alcohol-test positive (with protein instability) and presented normal titratable acidity, characterizing that the milk instability observed in the study did not originate from the presence of lactic acid. Over the next two years, the same researcher analyzed 2,396 milk samples in a mesoregion of the Southern country and found out that $55.2 \%$ of them had UNAM. In the state of Rio de Janeiro, Donatele et al. (2003) found out that $59.6 \%$ of the dairy cows analyzed produced $72{ }^{\circ} \mathrm{GL}$ Alizarol test positive milk, with no known factor determining acidification. It was observed that $13.6 \%$ of the positive samples had acidity between 14 and $18^{\circ} \mathrm{D}$, that is, within the normal standard established by the Brazilian legislation.

Roma Jr. et al. (2007) conducted a study analyzing 2,981 samples from the states of Minas Gerais, Rio de Janeiro and São Paulo, from October 2005 to September 2006. The authors found that $7.4 \%$ were classified as UNAM presenting coagulation in the test with $78{ }^{\circ} \mathrm{GL}$ of ethanol. The highest incidence period was in early Autumn (March), with a fall from early Spring (September). This pattern was related to the low quality of forages between the periods mentioned. Battaglini et al. (2016) analyzed 322 samples of raw milk, with $72{ }^{\circ} \mathrm{GL}$ alcohol test, and $92(28.6 \%)$ were classified as normal milk, $138(42,8 \%)$ as UNAM and $92(28.6 \%)$ as acid milk. This occurrence was similar to that found by Zanela et al. (2009), with occurrence ranging between 30 and $40 \%$. In studies conducted by Fischer et al. (2012), in which unstable milk samples were evaluated at different alcohol concentrations, the result pointed out that the higher the concentration used, the higher the number of cases of UNAM.

\section{UNAM Losses to Dairy Industry}

There is a close relationship between the composition of milk and its industrial yield, which is attributed to the casein fraction. Santos and Fonseca (2007) reported that a decrease of $0.5 \%$ in total solids or $0.1 \%$ in protein may mean a loss of 5 tons of milk powder or 1 ton of cheese, respectively, for each million liters of processed milk. UNAM causes much damage to the dairy industry, as casein becomes unstable as temperatures rise during thermal processing, which can promote milk coagulation and protein deposition on equipment. This can lead to a higher number of disruptions to cleaning, a problem that does not make processing impossible 
but generates difficulties and increased costs (SILVA et al., 2012). Also, this casein instability is associated with UHT milk gelatinization and it is one of the major problems affecting this product. UHT milk is one of the most consumed dairy products, given its practicality of preservation and use and also its long commercial life (CLAEYS et al., 2013; MCAULEY et al., 2016). According to Fischer et al. (2012), the use of UNAM milk in industry causes a reduction in dairy processing yields, as this type of milk may have lower levels of lactose, protein and in some situations fat. However, Zanela, Fischer and Ribeiro (2006) conducted an experiment in which milk from Jersey cows with a positive and negative alcohol content of $76^{\circ} \mathrm{GL}$ that was subjected to the process of making the beaten yogurt, where no changes in fermentation time, $\mathrm{pH}$ and viscosity were observed of whipped yoghurt made with UNAM. Costabel (2009) used 72 and $80{ }^{\circ} \mathrm{GL}$ alcohol-unstable milk in the industrial processing of cheese and observed that the percentage of protein retention in the clot was higher in the samples with $72{ }^{\circ} \mathrm{GL}$ alcohol instability. Those unstable to $80{ }^{\circ} \mathrm{GL}$ alcohol had a higher percentage of fat retention and total solids. However, this did not result in changes in industrial yield and no significant differences were observed between cheese processing with 72 and $80{ }^{\circ} \mathrm{GL}$ alcohol test positive and negative samples. Today, the use of UNAM is still viewed with suspicion by the industry and no more appropriate action is defined when this type of milk is diagnosed, except for disposal on the farm.

\section{How to Diagnose UNAM}

When the alcohol test on the farm shows a positive result for a milk without acidity, the carrier can boil this milk. If it precipitates, it is really a case of sour milk, but if it remains stable at boiling, the acidity test ( $\mathrm{pH}$ or Dornic) should be applied. If the $\mathrm{pH}$ result is between 6.6 and 6.8 or Dornic is between 14 and $18^{\circ} \mathrm{D}$, it is UNAM. Zanela (2009) exemplified these results in a UNAM diagnostic flowchart (Figure 4). 
Figure 4 Flow chart of UNAM diagnosis.

\section{FLOW CHART FOR UNAM DIAGNOSIS}

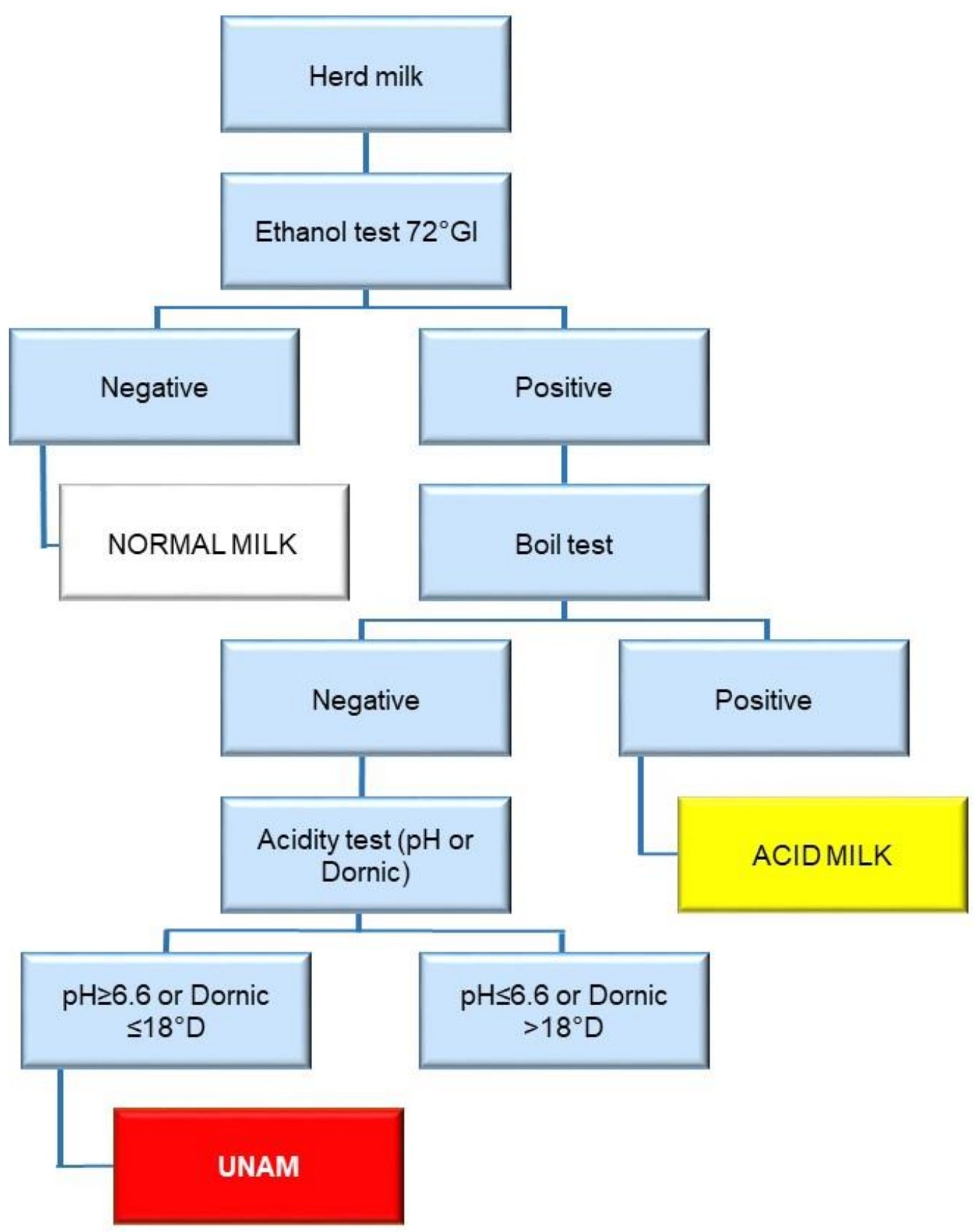

Source: Zanela (2009). 


\section{Causes of UNAM}

UNAM is reported as a multifactorial problem, and its causes are not yet fully understood. Cases usually occur due to a nutritional imbalance that the animal undergoes and due to the influence of seasonality, with the highest frequency of cases of UNAM during autumn (FISCHER, 2012). There is a large variation in incidence between times of the year, occurring mainly during the pasture in-betweens (at the end of the Summer pasture cycle, associated with the lack of Winter pastures). Other causes, such as diets with mineral imbalance, acid-base changes in animals, sudden changes in diet (BARROS, 2001), energy deficiency (PONCE; HERNÁNDEZ, 2001), malnutrition (ZANELA, 2004) and advanced stage of lactation may also promote instability. There are indications that high fiber silages and excess protein concentrates, factors that can alter the calcium-magnesium balance, may also lead to positive alcohol test reactions (GABBI et al., 2016; WERNCKE et al., 2016). Digestive and/or metabolic changes were related to decreased milk stability, possibly due to metabolic acidosis induced by ruminal acidosis (PONCE; HERNANDES, 2001) or the addition of anionic salts to the diet during lactation to induce metabolic acidosis (MARQUES et al., 2011), where the reduction of stability was related to the reduction of $\mathrm{pH}$ and the increase of ionic calcium.

Heat stress is also one of the causes of UNAM, as studies by Faria et al. (2017) Holstein cows were subjected to high temperatures and without access to shade for five days and were perceived as a significant reduction in milk stability on alcohol test, with values reached 70.83 ${ }^{\circ} \mathrm{GL}$. The authors suggest a reduction in stability as a result of metabolic acidosis, as claimed by Marques et al. (2011), in compensatory response to respiratory alkalosis triggered by increased respiratory rates.

Dietary restriction with consequent malnutrition or nutritional imbalance stands out for reducing milk stability in the alcohol test. The restriction, caused by the reduction of 40 to $50 \%$ in the amount of food, reduced milk production and increased the frequency of UNAM occurrence (ZANELA et al., 2006). Barbosa et al. (2012) found out that milk from cows subjected to dietary restriction showed more instability to the alcohol test. In these experiments, the pictures of UNAM were quickly established, about 2 days after the change in the animals' diet. Fruscalso et al. (2013) concluded that low availability of dry matter in pasture or restriction of grazing time are also considered forms of food restriction. The $50 \%$ reduction in pasture supply (Tifton 85) decreased the minimum alcohol concentration required to destabilize the samples from 75.8 to $69^{\circ} \mathrm{GL}$. According to Stumpf et al. (2013), the relationship between dietary restriction and reduced stability could be related to increased permeability of tight junctions between mammary epithelial cells. Consequently, there is a greater influx of sodium and eventually paracellular chlorides, which would increase ionic strength or promote saline 
imbalance and, consequently, reduce the net negative charge between casein micelles, increasing their chances of coagulation. In contrast, some experiments were performed in an attempt to correct the UNAM problem, such as the studies by Marques et al. (2010), who, using diets corrected for energy and protein signaled improvement in results with lower incidence of the problem. Oliveira (2015) adjusted the diet of animals fed on sorghum silage, elephant grass, and commercial concentrate, using the same nutrients, but to reach $100 \%$ of the requirements according to the NRC (2001), and found that the adjustment increased milk stability. In general, a balanced diet while maintaining the nutritional requirements of animals improves milk stability when facing the alcohol testing, but the total recovery of stability may take from one to three weeks, as each animal organism responds differently.

\section{Conclusions and Future Perspectives}

According to what has been presented, it can be concluded that the biggest challenge faced by the dairy industry in Brazil today is to obtain quality milk to maintain its heat stability. This prevents the precipitation of casein micelles in the equipment during the industrial process, which would result in clogging and blockage, and allows this raw material to obtain excellent yield in dairy products.

Another relevant factor in the Brazilian dairy sector is its undeniable social and economic importance. However, unlike European and North American countries, Brazil still has microbiological quality problems in milk, needing to apply the alcohol test as a guarantee of safe milk uptake. Changes in milk stability in alcohol test are described in different regions of the world and in Brazil as a serious and multifactorial problem and for causes not yet well understood, but which cause great damage to all links in the milk production chain, since UNAM even without high acidity is rejected and undervalued by the dairy industry.

Alcohol test is still considered a good alternative because it is fast, practical and inexpensive, but what is expected from quality regulatory bodies such as MAPA is that for the coming years this test will be abolished as a method for classifying raw material quality in the dairy industry. For such an event to occur, milk produced in the country can no longer present microbiological problems or the test must be reviewed and replaced, to offer greater reliability in the results and avoid losses for both dairy farmers and industry.

\section{Acknowledgments}

We would like to thank CNPq (Conselho Nacional de Desenvolvimento Científico e Tecnológico). 


\section{REFERENCES}

ANEMA, S. G.; LI, Y. Association of denatured whey proteins with casein micelles in heated reconstituted skim milk and its effect on casein micelle size. Journal of Dairy Research, v. 70, n. 1, p. 73-83, 2003.

BAGLINIÈRE, F., TANGUY, G., SALGADO, R. L., JARDIN, J., ROUSSEAU, F., ROBERT, B., HAREL-OGER, M., VANETTI, M. C. D.; GAUCHERON, F. Ser2 from Serratia liquefaciens L53: A new heat-stable protease able to destabilize UHT milk during its storage. Food Chemistry, v. 229, p. 104-110, 2017.

BARBOSA, C. P, BENEDETTI, E., RIBEIRO, S. C. A; GUIMARÃES, E. C. Relação entre contagem de células somáticas (CCS) e os resultados do "Califórnia Mastitis Test" (CMT), no diagnóstico de mastite bovina. Bioscience Journal, v. 18, n. 1, p. 93-102, 2008.

BARBOSA, R. S., FISCHER, V., RIBEIRO, M. E. R., ZANELA, M. B., STUMPF, M. T., KOLLING, G. J., SCHAFHÄUSER JÚNIOR, J., BARROS, L. E.; EGITO, A. S. Caracterização eletroforética de proteínas e estabilidade do leite em vacas submetidas à restrição alimentar. Pesquisa Agropecuária Brasileira, v. 47, n. 4, p. 621-628, 2012.

BARROS, L.; DENIS, N.; GONZÁLEZ, A.; NÚÑEZ, A. Prueba del alcohol en leche y relación con calcio iónico. Práticas Veterinárias. Publicación del Centro Veterinario de FloridaUruguay, v. 9, p. 315-325, 1999.

BARROS, L. Problemas de calidad de leche asociados a la alimentación. Estabilidad de la leche. In: Jornadas de la lechería. Instituto Nacional de Investigaciones Agropecuarias, Uruguay, 58-68, 2002.

BARROS, L. Transtornos metabólicos que afetam a qualidade do leite. In: González, F.H.D.; Dürr, J.W.; Fontaneli, R.S. (Ed.). Uso do leite para monitorar a nutrição e metabolismo de vacas leiteiras. Porto Alegre: Ed. da UFRGS, p. 44-57, 2001.

BATTAGLINI, A.P.P., BELOTI, V., FAGNANI, R., TAMANINI, R.; DUNGA, K. Microbiology and physical chemical characterization of unstable non-acid milk according to the seasons. Revista Brasileira de Medicina Veterinária, v. 35, n. 1, p. 26-32, 2013.

BELOTI, V. Leite Obtenção, Inspeção e Qualidade (1st edn). Londrina-PR, Brazil: Ed. Planta, $2015,417 \mathrm{p}$.

BOTARO, B. G., LIMA, Y. V. R., CORTINHAS, C. S., SILVA, L. F. P., RENNÓ, F. P., SANTOS, M.V. Effect of the kappa-casein gene polymorphism, breed and seasonality on physicochemical characteristics, composition and stability of bovine milk. Revista Brasileira de Zootecnia, v. 38, p. 2447-2454, 2009.

BRASIL. Regulamento técnico para fixação de identidade e qualidade do leite UHT (UAT). Diário Oficial da República Federativa do Brasil. Brasília: Ministério de Estado da Agricultura, Pecuária e Abastecimento. Portaria n. 370, de 4 de setembro de 1997.

BRASIL. Instrução Normativa n ${ }^{\circ}$ 51, de 18 de setembro de 2002. Diário Oficial da União, Brasília, 19 de setembro de 2002. Ministério da Agricultura, Pecuária e Abastecimento.

BRASIL. Instrução Normativa n ${ }^{62}$, de 29 de dezembro de 2011. Diário Oficial da União, Brasília, 29 de dezembro de 2011, Brasil. 
BRASIL. Instrução Normativa No 76, de 26 de novembro de 2018. Ministério de Agricultura, Pecuária e Abastecimento (MAPA). Diário Oficial da União, Brasília, 26 de novembro de 2018, Brasil.

BRASIL. Instrução Normativa No 77, de 26 de novembro de 2018. Ministério de Agricultura, Pecuária e Abastecimento (MAPA). Diário Oficial da União, Brasília, 26 de novembro de 2018, Brasil.

BUENO, V. F. F. et al. Contagem bacteriana total do leite: relação com a composição centesimal e o período do ano no Estado de Goiás. Revista Brasileira de Ciência Veterinária, v. 15, n. 1, p. 40-44, 2008.

CAPPOZZO, J. C, KOUTCHMA, T.; BARNES, G. Chemical characterization of milk after treatment with thermal (HTST and UHT) and nonthermal (turbulent flow ultraviolet) processing technologies. Journal of Dairy Science, v. 98, p. 5068-5079, 2015.

CHANDRAKANT, A. D., SINGH, H. Milk Protein Interactions. Reference Module in Food Science, v. 1, 2018.

CHAVAN, R.S., SEHRAWAT, R., MISHRA, V., BHATT, S. Milk: processing of milk. In Encyclopedia of Food and Health, Academic Press, Oxford, pp 729-735, 2016.

CHAVEZ, M. S., NEGRI, L. M., TAVERNA, M. A.; CUATRÍN, A. Bovine milk composition parameters affecting the ethanol stability. Journal of Dairy Research, v. 71, p. 1-6, 2004.

CHEN, B., LEWIS, M. J., GRANDISON, A. S. Effect of seasonal variation on the composition and properties of raw milk destined for processing in the UK. Food Chemistry, v. 158, p. 216223, 2014.

CHRAMOSTOVÁ, J., MÜHLHANSOVÁ, A., BINDER, M., STRMISKA, V., ČURDA, L., HANUŠ, O., KOPECKÝ, J., KLIMEŠOVÁ, M., DRAGOUNOVÁ, H., SEYDLOVÁ, R.; NĚMEČKOVÁ, I. Heat stability of raw ewe and goat milk. Mlékařské listy - zpravodaj, v. 27 , n. 3, p. 22-26, 2016.

CLAEYS, W. L., CARDOEN, S., DAUBE, G., DE BLOCK, J., DEWETTINCK, K., DIERICK, K., DE ZUTTER, L., HUYGHEBAERT, A., IMBERECHTS, H., THIANGE, P., VANDENPLAS, Y., HERMAN, L. Raw or heated cow milk consumption: review of risks and benefits. Food Control, v. 31, p. 251-262, 2013.

CLAEYS, W. L., VERRAES, C., CARDOEN, S., DE BLOCK. J., HUYGHEBAERT, A., RAES, K., DEWETTINCK, K.; HERMAN, L. Consumption of raw or heated milk from different species: an evaluation of the nutritional and potential health benefits. Food Control, v. 42, p. 188-201, 2014.

COSTABEL, L. M., CUATRÍN, A. L., PAEZ, R. B., TAVERnA, M. A., WALTER, E., CAMPOS, S. N., ROBLEDO, M., ADORNI, B. Estudio de la relación entre aptitud a La coagulación pro cuajo y prueba de alcohol en muestras de leche de vacas individuales. In:52 Conferência Internacional do Leite Instável, 1.,2009. Pelotas. Anais... Pelotas: Embrapa Clima Temperado, 2009. 1 CD-ROM 
CRUDDEN, A., AFOUFA-BASTIEN, D., FOX, P. F., BRISSON, G., KELLY, A. L. Effect of hydrolysis of casein by plasmin on the heat stability of milk. International Dairy Journal, v. 15, p. 1017-1025, 2005.

DEETH, H. C, LEWIS, M. J. High Temperature Processing of Milk and Milk Products (pp.177-260). Sussex Occidental, London, UK: Ed. John Wiley \& Sons Ltd, 2017.

DONATELE, D. M., VIEIRA, L. F. P., FOLLY, M. M. Relação do teste de Alizarol a 72\% (v/v) em leite in natura de vaca com acidez e contagem de células somáticas: análise microbiológica. Higiene Alimentar, v. 17, p. 95-100, 2003.

EMBRAPA. Empresa Brasileira de Pesquisa Agropecuária. Anuário do leite 2018. Embrapa Gado de Leite, 2018. Disponível em: www.embrapa.br/busca-de-publicacoes/-

/publicacao/1094149/anuario-leite-2018-indicadores-tendencias-e-oportunidades-para-quemvive-no-setor-leiteiro.

FAGNANI, R., BELOTI, V., BATTAGLINI, A. P. P. Acid-base balance of dairy cows and its relationship with alcoholic stability and mineral composition of milk. Pesquisa Veterinária Brasileira, v. 34, p. 398-410, 2014.

FAGNANI, R., BATTAGLINI, A. P. P., BELOTI, V., URBANO, A., CAMARGO BRONZOL, J. Alcohol Stability of Milk from the Perspective of X-Ray Diffractometry. Food Biophysics, v. 11, n. 2, p. 198-205, 2016.

FAO. Milk testing and quality control. Training Programme for Small Scale Dairy Sector and Dairy Training Institute - Naivasha, 1996. Disponível em:

http://www.fao.org/ag/againfo/resources/documents/MPGuide/ mpguide2.htm.

FARIA, P. F., RANGEL, A. H. N., URBANO, S. A., BORBA, L. H. F., GALVÃO JÚNIOR, J. G. B., SILVA, E. R. Unstable milk occurrence in the semiarid region and its relation with the physicochemical characteristics of milk. Livestock Research for Rural Development, v. 29, n. 1, p. 1-8, 2017.

FISCHER, V., RIBEIRO, M. E. R., ZANELA, M. B., MARQUES, L. T., ABREU, A. S., MACHADO, S. C., FRUSCALSO, V., BARBOSA, R. S., STUMPF, M. T. Leite instável não ácido: um problema solucionável? Revista Brasileira de Saúde e Produção Animal, v. 13, n. 3 , p. 838-849, 2012.

FOX, P. F. Heat-induced changes in milk preceding coagulation. Journal of Dairy Science, v. 64, p. 21-27, 1981.

FOX, P. F., BRODKORB, A. The casein micelle: Historical aspects, current concepts and significance. International Dairy Journal, v. 18, p. 677-684, 2008.

FRUSCALSO, V., STUMPF, M. T., MCMANUS, C. M., FISCHER, V. Feeding restriction impairs milk yield and physicochemical properties rendering it less suitable for sale. Scientia Agricola, v. 70, n. 4, p. 237-241, 2013.

GABBI, A. M., MCMANUS, C. M., ZANELA, M. B., STUMPF, M. T., BARBOSA, R. S., FRUSCALSO, V., THALER NETO, A., SCHMIDT, F. A., FISCHER, V. Milk traits of lactating cows submitted to feed restriction. Tropical Animal Health Production, v. 48, p. 37-43, 2016. 
GAUCHER, I., MOLLÉ, D., GAGNAIRE, V., GAUCHERON, F. Effects of storage temperature on physico-chemical characteristics of semi-skimmed UHT milk. Food Hydrocolloids, v. 22, p. 130-143, 2008.

GAUCHER, I., TANGUY, G., FAUQUANT, J., JARDIN, J., ROUSSEAU, F., ROBERT, B., MADEC, M.N., GAUCHERON, F. Proteolysis of casein micelles by Pseudomonas fluorescens CNRZ 798 contributes to the destabilization of UHT milk during its storage. Dairy Science \& Technology, v. 91, p. 413-429, 2011.

GAUCHERON, F. The minerals of milk. Reproduction Nutrition Development, v. 45, p. 473483, 2005.

GAZI, I., VILALVA, I. C., HUPPERTZ, T. Plasmin activity and proteolysis in milk protein ingredients. International Dairy Journal, v. 38, p. 208-212, 2013.

HANUŠ, O., SAMKOVÁ, E., CHLÁDEK, G., KLIMEŠOVÁ, M., ROUBAL, P., NĚMEČKOVÁ, I., JEDELSKÁ, R., KOPECKÝ, J. Raw cow milk thermostability and its relations to other indicators. Acta Universitatis Agriculturae et Silviculturae Mendelianae Brunensis, v. 66, n. 5, p. 1127 - 1134, 2018.

HOLT, C. An equilibrium thermodynamic model of the sequestration of calcium phosphate by casein micelles and its application to the calculation of the partition of salts in milk. The European Biophysics Journal, v. 33, p. 421-434, 2004.

HORNE, D. S., MUIR, D. D. Alcohol and heat stability of milk protein. Journal of Dairy Science, v. 73, p. 3613-3626, 1990.

HORNE, D. S. Ethanol stability and milk composition. In MCSWEENEY, P. L. H., O'MAHONEY, J. A. (Eds.), Advanced dairy chemistry. Vol. 1B. Proteins: Applied aspects (4th edn., pp. 225-246). New York, NY, USA: Springer New York. 2016. 482p.

HUPPERTZ, T. Heat stability of transglutaminase-treated milk. International Dairy Journal, v. 38, n. 2, p. 183-186, 2013.

HUPPERTZ, T. Heat stability of milk. In MCSWEENEY, P. L. H., O’MAHONY, J. A. (Eds.), Advanced Dairy Chemistry, fourth ed., vol. 1B. Springer, New York, NY, pp. 179-196. 2016.

KASSA, F., YILMA, Z., ASSEFA, G., BEKELE, T., GOJAM, Y., NEBIYU, R., KASSA, B. Evaluation of Lactoperoxidase system as raw milk preservative at different storage temperature conditions in the central highlands of Ethiopia. Livestock Research for Rural Development, v. 25, Article \#68, 2013.

KELLY, A. L., MCSWEENEY, P. L. H. Indigenous proteinases in milk. In FOX, P. F., MCSWEENEY, P. L. H. (Eds.), Advanced Dairy Chemistry, vol. 1: proteins, 3 editions (p. 495-544). New York: Kluwer Academic/Plenum Publishers. 2003.

LE, T. T., PHAN, T. T. Q., VAN CAMP, J., DEWETTINCK, K. Milk and dairy polar lipids: occurrence, purification, and nutritional and technological properties. In Polar lipids. Elsevier, pp 91-143. 2015. 
LEITNER, G., LAVON, Y., MATZRAFI, Z., BENUN, O., BEZMAN, D., MERIN, U. Somatic cell counts, chemical composition and coagulation properties of goat and sheep bulk tank milk. International Dairy Journal, v. 58, p. 9-13, 2016.

LIN, Y., O’MAHONY, J. A., KELLY, A. L., GUINEE, T. P. Seasonal variation in the composition and processing characteristics of herd milk with varying proportions of milk from spring-calving and autumn-calving cows. Journal of Dairy Research, v. 84, n. 4, p. 444-452, 2017.

LOPES, L. C. Composição e características físico-químicas do leite instável não ácido (LINA) na região de Casa Branca, São Paulo. Dissertação, Faculdade de Zootecnia e Engenharia de Alimentos, São Paulo, Brasil. 2008. Disponível em: www.teses.usp.br/teses/disponiveis/74/74131/tde-29042008-103024/pt-br.php.

MACHADO, S. C., FISCHER, V., STUMPF, M. T., STIVANIN, S. C. B. Seasonal variation, method of determination of bovine milk stability, and its relation with physical, chemical, and sanitary characteristics of raw milk. Revista Brasileira de Zootecnia, v. 46, n. 4, p. 340-347, 2017.

MARA, O., ROUPIE, C., DUFFY, A., KELLY, A. L. The curd-forming properties of milk as affected by the action of plasmin. International Dairy Journal, v. 8, n. 9, p. 807-812, 1998.

MARQUES, L. T., ZANELA, M. B., RIBEIRO, M. E. R., STUMPF, W., FISCHER, V. Ocorrência do leite instável ao álcool 76\% e não ácido (LINA) e efeito sobre os aspectos físicoquímicos do leite. Revista Brasileira de Agrociência, v. 1, n.1, p. 91-97, 2007.

MARQUES, L. T., FISCHER, V., ZANELLA, M. B. Fornecimento de suplementos com diferentes níveis de energia e proteína para vacas Jersey e seus efeitos sobre a instabilidade do leite. Revista Brasileira de Zootecnia, v. 39, n. 12, p. 2724-2730, 2010.

MARQUES, L. T., FISCHER, V., ZANELA, M. B., RIBEIRO, M. E. R., STUMPF JÚNIOR, W., RODRIGUES, C. M. Produção leiteira, composição do leite e perfil bioquímico sanguíneo de vacas lactantes sob suplementação com sal aniônico. Revista Brasileira de Zootecnia, v. 40, n. 5, p. 1088-1094, 2011.

MARTINS, C. M. M. R., ARCARI, M. A., WELTER, K. C., NETTO, A. S, OLIVEIRA, C. A. F., SANTOS, M. V. Effect of dietary cation-anion difference on performance of lactating dairy cows and stability of milk proteins. Journal of Dairy Science, v. 98, n. 4, p. 2650-2661, 2015.

MCAULEY, C. M., SINGH, T. K., HARO-MAZA, J. F., WILLIAMS, R., BUCKOW, R. Microbiological and physicochemical stability of raw, pasteurised or pulsed electric field-treated milk. Innovative Food Science \& Emerging Technologies, v. 38, p. 365-373, 2016.

MCMAHON, D. J. Letter to the editor. The dynamic casein supramolecule: A response to Horne. Journal of Dairy Science, v. 93, n. 8, p. 3404, 2010.

MELETHARAYIL, G. H., PATEL, H. A., METZGER, L. E., MARELlA, C., HUPPERTZ, T. Influence of partially demineralized milk proteins on rheological properties and microstructure of acid gels. Journal of Dairy Science, v. 101, p. 1864-1871, 2018. 
MOLINA, L. H., GONZÁLEZ, R., BRITO, C., CARRILlO, B., PINTO, M. Correlacion entre la termoestabilidad y prueba de alcohol de la leche a nivel de un centro de acopio lechero. Archivo de Medicina Veterinaria, v. 33, p. 233-240, 2001.

MURPHY, S. C., MARTIN, N. H., BARBANO, D. M., WIEDMANN, M. Influence of raw milk quality on processed dairy products: how do raw milk quality test results relate to product quality and yield? Journal of Dairy Science, v. 99, p. 10128-10149, 2016.

NEGRI, L., CHAVEZ, M., TAVERNA, M., ROBERTS, L., SPERANZA, J. Fatores que afectan la estabilidad térmica y la prueba de alcohol en leche cruda de calidad higiénica adecuada: informe técnico final del proyecto. INTA EEA/INTI CITIL, 2001. 27p. Disponível em:

www.scielo.br/scielo.php?script=sci_nlinks\&ref $=000088 \&$ pid $=S 0100204 X 20060005000160001$ $\underline{1 \& \operatorname{lng}=\mathrm{pt}}$

O’CONNELL, J. E., FOX, P. F. Heat Treatment of Milk: Heat Stability of Milk. In Encyclopedia of Dairy Sciences, 2nd Edition, p. 744-749, 2016.

O’CONNELL, A., KELLY, A. L., TOBIN, J., RUEGG, P. L., GLEESON, D. The effect of storage conditions on the composition and functional properties of blended bulk tank milk. Journal of Dairy Science, v. 100, p. 1-13, 2017.

OLIVEIRA, C. A. F., LOPES, L. C., ROSIM, R. E., FERNANDES, A. M., CORASSIN, C. H. Composition, somatic cell count and casein fractions of ethanol unstable milks. Acta Scientiarum: Technology, v. 35, n. 1, p. 153-156, 2013.

OLIVEIRA, L. R., OLIVEIRA, N. J. F., GONÇALVES, A. F., SANTOS, C. A., MOURTHE, M. H. F., MATIAS, A. D. Parâmetros físicos do leite e ocorrência de leite instável não ácido em diferentes municípios do norte de Minas Gerais. Caderno de Ciências Agrárias, v. 7, n. 1, p. 150-155, 2015.

OMOARUKHE, E. D., ON-NOM, N., GRANDISON, A. S., LEWIS, M. J. Effects of different calcium salts on properties of milk related to heat stability. International Journal of Dairy Technology, v. 63, p. 504-511, 2010.

O'SUlliVAN, O., COTTER, P. D. Microbiota of raw milk and raw milk cheeses. In Cheese (4 edition). Academic Press, San Diego, pp. 301-316, 2017.

PECORARI, M., FOSSA E., AVANZINI, G., MARIAN, P. Milk with abnormal coagulation: acidity, chemical composition and observation on the metabolic profile of the cow. Scienza $\mathbf{e}$ Tecnica Lattiero Casiare, v. 23, n. 4, p. 263-278, 1984.

PEREZ Jr., J. R. O leite como ferramenta do monitoramento nutricional. In GONZÁLEZ, F. H. D., DÜRR, J. W., FONTANELI, R. S. (1 st edn.). Uso do leite para monitorar a nutrição e metabolismo de vacas leiteiras. Porto Alegre, Brasil: Ed. UFRGS, p.44-57, 2001.

PONCE, C., HERNÁNDEZ, R. Propriedades físico-químicas do leite e sua associação com transtornos metabólicos e alterações na glândula mamária. In Uso do leite para monitorar a nutrição e metabolismo de vacas leiteiras ( 1 st edn). Porto Alegre, Brasil: Ed. Félix H. D. p. 58-68, 2001. 
RADFORD, S. J., DICKINSON, E., GOLDING, M. Stability and rheology of emulsions containing sodium caseinate: combined effects of ionic calcium and alcohol. Journal of Colloid and Interface Science, v. 274, n. 2, p. 673-686, 2004.

RAMIRES, C. H., BERGER, E. L., ALMEIDA, R. Influência da qualidade microbiológica da água sobre a qualidade do leite. Archives of Veterinary Science, v. 14, n. 1, p. 36-42, 2009.

RATHNAYAKE, R., MANGALIKA, U., ADIKARI, A, NAYANANJALIE, W. Changes in compositional and keeping quality parameters of cow milk on ethanol stability. International Journal of Livestock Research, v. 6, p. 83-89, 2016.

RENHE, I. R. T., INDRIS, L. M., CORREDIG, M. Effect of calcium chelators on heat stability and heat-induced changes in milk microfiltered concentrates. International Dairy Journal, v. 82, p. 4-10, 2018.

ROBITAILLE, G., BRITTEN, M., PETITCLERC, D. Effect of a differential allelic expression of kappa-casein gene on ethanol stability of bovine milk. Journal of Dairy Research, v. 68, p. 145$149,2001$.

ROMA Jr., L. C. Características quantitativas e qualitativas da proteína do leite produzido na região Sudeste. Tese. Escola Superior de Agricultura Luiz de Queiroz, Piracicaba, Brasil. 2007. Disponível em:

http://bdtd.ibict.br/vufind/Record/USP_dca8e786c9e5b2519914b16d13822586

SAMARŽIJA, D., ZAMBERLIN, Š., POGAČIĆ, T. Psychrotrophic bacteria and milk quality. MLjekarstvo, v. 62, n. 2, p. 77- 95, 2012.

SANTOS, S. A., SILVA, A. S., SANTOS, M. A. J., SANTOS, M. B., SILVA, R. A. Avaliação físico-química de leite bovino utilizando pó de repolho roxo (Brassica oleracea var. capitata). In Congresso Brasileiro de Química, 53, 2013, Natal. Química e sociedade: motores da sustentabilidade: Anais... Natal: ABQ; UFRN, Brasil. 2013.

SANTOS, M. V., FONSECA, L. F. L. Estratégias para controle de mastite e melhoria da qualidade do leite. (1. st edn). Barueri, Brasil: Manole Publishers. 2007. 325p.

SILVA, P. H. F. Leite UHT: fatores determinantes para sedimentação e gelificação. (1. st edn). Juiz de Fora, Brazil: Templo. 2004. 250p.

SILVA, L. C. C., BELOTI, V., TAMANINI, R., YAMADA, A. K., GIOMBELLI, C. J., SILVA, M. R. Estabilidade térmica da caseína e estabilidade ao álcool 68, 72, 75 e 78\%, em leite bovino. Revista do Instituto de Laticínios Cândido Tostes, v. 67, p. 55-60, 2012.

SILVA, N. N., PIOT, M., DE CARVALHO, A. F., VIOLLEAU, F., FAMEAU, A. L., GAUCHERON, F. pH-induced demineralization of casein micelles modifies their physicochemical and foaming properties. Food Hydrocolloids, v. 32, p. 322-330, 2013.

SINGH, H. Heat Stability of Milk. International Journal of Dairy Technology, v. 57, n. 2/3, p. 111-119, 2004.

SOBHANI, S., VALIZADEH, R., NASERIAN, A. Alcohol stability of milk and its relation to milk and blood composition in Holstein dairy cows. Journal of Animal Science, v. 80, n. 1 /Journal of Dairy Science, v. 85, n. 1, 1998. 
SORMOLI, M. E., DAS, D., LANGRISH, T. A. G. Crystallization behavior of lactose/sucrose mixtures during water-induced crystallization. Journal of Food Engineering, v. 116, n. 4, p. 873-879, 2013.

STUMPF, M. T., FISCHER, V., MCMANUS, C. M., KOLLING, G. J., ZANELA, M. B., SANTOS, C. S., ABREU, A. S., MONTAGNER, P. Severe feed restriction increases permeability of mammary gland cell tight junctions and reduces ethanol stability of milk. Animal, v. 7, n. 7, p. 1137-1142, 2013.

TRONCO, V. M. Manual para a Inspeção da Qualidade do Leite. Santa Maria, Brasil: Ed. UFSM. 2013. 250p.

TSENKOVA, R., ATANASSOVA, S., KAWANO, S. Somatic cell count determination in cow's milk by near-infrared spectroscopy: A new diagnostic tool. Journal of Animal Science, v. 79, p. 2550-2557, 2001.

TSIOULPAS, A., LEWIS, M. J., GRANDISON, A. S. Effect of minerals on casein micelle stability of cows' milk. Journal of Dairy Research, v. 74, n. 2, p. 167-173, 2007.

VIZZOTTO, E. F., OLIVEIRA, E. R., FISCHER, V., ABREU, A. S., STUMPF, M. T., KOLLING, G. J., WANDERER, M. pH da solução alcoólica usada no teste do álcool e sua influência na estabilidade do leite bovino. In: Congresso Internacional de Leite, 21, 2012, Anais...Goiânia, Brazil. 2012.

WEBER, B. A., NIELSEN, S. S. Isolation and partial characterization of a native serine-type protease inhibitor from bovine milk. Journal of Dairy Science, v. 74, p. 717-764, 1991.

WERNCKE, D., GABBI, A. M., ABREU, A. S., FELIPUS, N. C., MACHADO, N. L., CARDOSO, L. L., SCHMID, F. A., ALESSIO, D. R. M., FISCHER, V., THALER NETO, A. Qualidade do leite e perfil das propriedades leiteiras no sul de Santa Catarina: abordagem multivariada. Arquivo Brasileiro de Medicina Veterinária e Zootecnia, v. 68, p. 506-516, 2016.

WHITE, G. H., ZAVIZION, B., O’HARE, K., GILMORE, J., GUO, M. R., KINDTEDT, P., POLITIS, I. Distribution of plasminogen activator in different fractions of bovine milk. Journal of Dairy Research, v. 62, p. 115-122, 1995.

WINK, C. A., THALER NETO, A. Diagnóstico da adequação de propriedades leiteiras em Santa Catarina às normas brasileiras de qualidade do leite. Revista de Ciências Agroveterinárias, v. 8, n. 2, p. 164-172, 2009.

YOSHIDA, S. Studies in the Utrecht abnormality of milk in the Miyuki Dairy Farm. Journal Japanese Applied Biology Science Hiroshima University, v. 19, p. 39-54, 1980.

ZANELA, M. B., FISCHER, V., RIBEIRO, M. E. R. Unstable non-acid milk and milk composition of Jersey cows on feed restriction. Pesquisa Agropecuária Brasileira, v. 41, p. 835-840, 2006. 
ZANELA, M. B., RIBEIRO, M. E. R., FISCHER, V., GOMES, J. F., STUMPF Jr, W. Ocorrência do leite instável não ácido no noroeste do Rio Grande do Sul. Arquivo Brasileiro de Medicina Veterinária e Zootecnia, v. 61, n. 4, p. 1009-1013, 2009.

ZANELA, M. B., KOLLING, G. J., RIBEIRO, M. E. R., FISCHER, V. Análises de composição e estabilidade do leite ao álcool. In Leche inestable. Desafios en el Cono Sur. Montevideo Uruguay: Ed. Universidad de la República. 2014.

ZANELA, M. B., RIBEIRO, M. E. R. LINA - Leite Instável Não Ácido. Pelotas, Brasil: Embrapa Clima Temperado, 2018. (Comunicado Técnico, 356) 